\title{
Artikel Penelitian
}

\section{Hubungan Kadar Albumin dan Kalsium Serum Pasien Sindrom Nefrotik pada Anak}

\author{
Yuliana $^{1}$, Ria Triwardhani², Djoko Handojo ${ }^{3}$, Dwi Retnoningrum²
}

\begin{abstract}
Abstrak
Pada keadaan hipoalbuminemia yang terjadi pada sindrom nefrotik, dapat menyebabkan hipokalsemia. Penurunan kalsium ekstrasel menimbulkan efek eksitasi sel saraf dan otot yang berakibat timbul tetani hipokalsemik. Tujuan: Menentukan hubungan kadar albumin dan kalsium serum pasien sindrom nefrotik pada anak. Metode: Penelitian ini adalah studi observasional analitik dengan pendekatan belah lintang terhadap 30 sampel yang memenuhi kriteria inklusi dan eksklusi. Sampel penelitian adalah pasien sindrom nefrotik pada anak yang berobat/dirawat di RSUP Dr. Kariadi dari Januari sampai Juli 2019. Hasil pemeriksaan albumin dan kalsium diambil dari rekam medis pasien. Uji analisis dilakukan dengan korelasi Spearman's. Hasil: Subjek terdiri dari $24(80 \%)$ lakilaki dan $6(20 \%)$ perempuan, berusia rata-rata 4,27 $( \pm 2,45)$ tahun. Hasil rata-rata kadar albumin serum 2,16 $( \pm 0,79)$ $\mathrm{g} / \mathrm{dL}$ dan kalsium serum 2,00 $( \pm 0,20) \mathrm{mmol} / \mathrm{L}$. Hasil analisis uji korelasi Spearman's untuk melihat hubungan kadar albumin dan kalsium serum pasien sindrom nefrotik pada anak menunjukkan $(r=0,623)$ dan $(p<0,001)$. Terdapat korelasi positif antara kadar albumin dan kalsium serum pasien sindrom nefrotik pada anak. Simpulan: Terdapat hubungan positif kuat kadar albumin dan kalsium serum pasien sindrom nefrotik pada anak.
\end{abstract}

Kata kunci: hipoalbuminemia, hipokalsemia. sindrom nefrotik

\section{Abstract}

Hypoalbuminemia occurs in children with nephrotic syndrome, can cause hypocalcemia. Decreasing extracellular calcium excites the nerve cells and muscles, which results in hypocalcemic tetany. Objectives: To determined the correlation of serum albumin and calcium levels in nephrotic syndrome patients in children. Methods: This study was an analytic observational study with a cross-sectional approach on 30 samples that met the inclusion criteria. The study sample was nephrotic syndrome patients children at RSUP Dr. Kariadi from January to July 2019. The results of albumin and calcium examination were taken from the patient's medical record. Test analysis was carried out using Spearman correlation. Results: Subjects consisted of 24 (80\%) men and 6 (20\%) women, with an average age of 4.27 $( \pm 2.45)$ years. The average serum albumin level was $2.16( \pm 0.79) \mathrm{g} / \mathrm{dL}$ and serum calcium was $2.00( \pm 0.20) \mathrm{mmol} / \mathrm{L}$. The results of the Spearman correlation test analysis to see the correlation between albumin and serum calcium levels of nephrotic syndrome patients in children showed $(r=0.623)$ and $(p=0,000)$. There was a positive correlation between serum albumin and calcium levels in nephrotic syndrome patients in children. Conclusion: There is a strong positive correlation between serum albumin and calcium levels in nephrotic syndrome patients in children.

Keywords: hypoalbuminemia, hypocalcemia, nephrotic syndrome

Affiliasi penulis: 1 Program Pendidikan Dokter Spesialis Patologi Klinik, Fakultas Kedokteran, Universitas Diponegoro, Semarang 2Bagian Patologi Klinik, Fakultas Kedokteran, Universitas Diponegoro, Semarang/RSUP Dr Kariadi Semarang. ${ }^{3}$ RSUD RA Kartini. Korespondensi: Fakultas Kedokteran, Universitas Diponegoro Jl. Prof. Soedarto No.13 Tembalang, Semarang, Email: yuliana040190@gmail.com. Telp: Telp:085275784891

\section{PENDAHULUAN}

Sindrom nefrotik merupakan suatu kelainan glomerulus yang ditandai dengan proteinuria, hipoproteinemia (hipoalbuminemia), dan edema. ${ }^{1-4}$ Sindrom nefrotik merupakan kelainan ginjal terbanyak dijumpai pada anak. Insiden di Indonesia diperkirakan 
enam kasus per tahun tiap 100.000 anak kurang dari 14 tahun. Sindrom nefrotik lebih banyak diderita oleh anak laki-laki daripada anak perempuan dengan perbandingan $2: 1 .^{4-6}$

Sindrom nefrotik terjadi karena peningkatan permeabilitas dinding kapiler glomerulus yang mengakibatkan proteinuria masif dan hipoalbuminemia. Penyebab terjadinya peningkatan permeabilitas dinding kapiler tersebut belum diketahui dengan pasti. ${ }^{7-11}$

Pada sindrom nefrotik, hipoalbuminemia disebabkan oleh proteinuria masif dengan akibat penurunan tekanan onkotik plasma. ${ }^{12-14}$ Pada keadaan hipoalbuminemia yang terjadi pada anak sindrom nefrotik, dapat menyebabkan hipokalsemia. Kurang dari setengah kalsium total serum berbentuk bebas atau terionisasi, sebagian besar berikatan dengan protein (terutama albumin), dan sekitar 10\% membentuk ikatan kompleks dengan anion seperti fosfat, sitrat, atau sulfat. ${ }^{15}$ lon kalsium merupakan komponen yang penting, tetapi yang umumnya diperiksa adalah kalsium serum total karena harga reagen yang mahal dan keterbatasan alat di rumah sakit.

Penurunan kalsium ekstrasel menimbulkan efek eksitasi sel saraf dan otot in-vivo, akibatnya timbul tetani hipokalsemik, yang ditandai oleh spasme ekstensif otot rangka, terutama mengenai otot-otot ekstremitas dan laring. ${ }^{16}$ Pada penelitian Garniasih et al serangan tetani terjadi pada pasien dengan kadar kalsium kurang dari $7 \mathrm{mg} / \mathrm{dL}$ (konversi: kurang dari 1,75 mmol/L). ${ }^{17}$ Penelitian ini dilakukan dengan tujuan untuk melihat hubungan antara kadar albumin dan kalsium serum pasien sindrom nefrotik pada anak.

\section{METODE}

Penelitian cross sectional ini telah dilakukan pada anak sindrom nefrotik yang berobat/dirawat di RSUP Dr. Kariadi bulan Januari sampai Juli 2019 Data diambil dari rekam medis pasien. Kriteria inklusi adalah anak dengan diagnosis sindrom nefrotik usia 114 tahun. Kriteria eksklusi adalah pasien yang telah mendapat terapi albumin maupun kalsium sebelumnya, terdapat kelainan hati, telah mendapat terapi kortikosteroid lebih dari satu tahun, pasien dengan malnutrisi berat, sindrom nefrotik dengan gagal ginjal akut. Data yang dicatat meliputi umur, jenis kelamin, hasil laboratorium albumin dan kalsium. Analisa statistik dari data yang diperoleh dilakukan secara komputerisasi. Uji normalitas Shapiro-Wilk digunakan untuk menentukan perbedaan signifikan dalam penyimpangan dari distribusi normal. Korelasi Spearman's untuk melihat hubungan antara kadar albumin dan kalsium serum pasien sindrom nefrotik pada anak. Penelitian ini sudah mendapatkan layak etik dari Komite Etik Penelitian Kesehatan (KEPK) RSUP Dr Kariadi dengan No.313/EC/KEPKRSDK/2019.

\section{HASIL}

Selama kurun waktu Januari sampai Juli 2019, pasien sindrom nefrotik yang berobat/dirawat di RSUP Dr Kariadi Semarang tercatat 30 kasus. Subjek penelitian terdiri dari laki-laki 24 (80\%) dan perempuan $6(20 \%)$. Subjek termuda berusia 1 tahun dan tertua berusia 10 tahun. Karakteristik umum subjek dapat dilihat pada Tabel 1.

Tabel 1. Karakteristik umum

\begin{tabular}{|c|c|c|c|c|}
\hline Variabel & $f$ & $\%$ & Rerata $\pm S D$ & $\begin{array}{c}\text { Median } \\
\text { (Min-Maks) }\end{array}$ \\
\hline Umur (tahun) & & & $4,27 \pm 2,45$ & $4(1-10)$ \\
\hline \multicolumn{5}{|l|}{ Jenis Kelamin } \\
\hline Laki-laki & 24 & 80 & & \\
\hline Perempuan & 6 & 20 & & \\
\hline
\end{tabular}

Tabel 2. Kadar albumin dan kalsium serum

\begin{tabular}{lcccc}
\hline Variabel & $\mathbf{n}$ & Rerata \pm SD & $\begin{array}{l}\text { Median } \\
\text { (Min-Maks) }\end{array}$ & $\mathbf{p}^{\varepsilon}$ \\
\hline $\begin{array}{l}\text { Albumin } \\
\text { (g/dL) }\end{array}$ & 30 & $2,16 \pm 0,79$ & 2,05 & 0,001 \\
Kalsium & 30 & $2,00 \pm 0,20$ & $(1,2-4,2)$ & \\
$(\mathrm{mmol} / \mathrm{L})$ & & & $(1,5-2,4)$ & $0,101^{*}$ \\
\hline Keterangan: ${ }^{*}$ Normal $(\mathrm{p}>0.05) ;{ }^{\text {E Shapiro-wilk }}$
\end{tabular}

Sebaran kadar albumin dan kalsium serum pada subjek penelitian terdapat pada Tabel 2. Kadar albumin rerata 2,16 $\pm 0,79 \mathrm{~g} / \mathrm{dL}$ dengan rentang nilai terendah 1,2 g/dL dan tertinggi 4,2 g/dL. Kadar kalsium rerata $2,00 \pm 0,20 \mathrm{mmol} / \mathrm{L}$, dengan rentang terendah $1,5 \mathrm{mmol} / \mathrm{L}$ dan tertinggi $2,4 \mathrm{mmol} / \mathrm{L}$. 
Keeratan hubungan tersebut dilakukan uji korelasi Spearman's, didapatkan hubungan positif kuat antara kadar albumin dan kalsium yang bermakna pasien sindrom nefrotik pada anak, dengan koefisien korelasi $r=0,623, p<0,001$. Pada Gambar 1, scatter plot membuktikan terdapat hubungan linier antara kadar albumin dan kalsium serum pasien sindrom nefrotik pada anak.

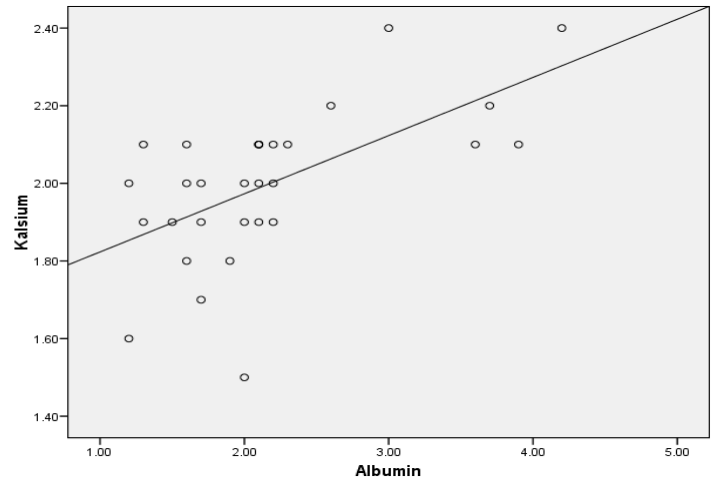

Gambar 1. Diagram sebar dan bentuk hubungan antara kadar albumin dan kalsium serum pada anak sindrom nefrotik

\section{PEMBAHASAN}

Pada sindrom nefrotik terjadi hipoalbuminemia akibat dari proteinuria yang disebabkan oleh peningkatan permeabilitas kapiler terhadap protein akibat kerusakan glomerulus. Pada sindrom nefrotik hipoalbuminemia disebabkan oleh proteinuria masif dengan akibat penurunan tekanan onkotik plasma. Untuk mempertahankan tekanan onkotik plasma maka hati berusaha meningkatkan sintesis albumin. Peningkatan sintesis albumin hati tidak berhasil menghalangi timbulnya hipoalbuminemia. Diet tinggi protein dapat meningkatkan sintesis albumin hati, tetapi dapat mendorong peningkatan ekskresi albumin melalui urin. ${ }^{12}$

Pada keadaan hipoalbuminemia yang terjadi pada anak sindrom nefrotik, dapat menyebabkan hipokalsemia. ${ }^{15}$ Sekitar $50 \%$ kalsium dalam sirkulasi berada dalam bentuk ion kalsium, 40\% terikat dengan protein (didominasi oleh albumin) dan $10 \%$ berada dalam bentuk anion. ${ }^{18,19}$ Tubuh membutuhkan kalsium untuk membentuk dan memperbaiki tulang dan gigi, membantu fungsi saraf, kontraksi otot, pembentukan darah dan berperan dalam fungsi jantung. Semua kalsium yang masuk kedalam tubuh (melalui makanan atau asupan) sebagian besar disimpan oleh tubuh dan tidak dibuang melalui urin atau feses. ${ }^{20}$

Ion kalsium plasma adalah kalsium yang aktif secara biologis dan konsentrasinya dikontrol secara ketat. Meskipun ion kalsium merupakan komponen yang penting, tetapi yang umumnya diperiksa adalah kalsium serum total. ${ }^{21}$ Kondisi yang mempengaruhi kadar albumin dalam plasma seperti sindrom nefrotik atau sirosis hepatis berefek pada pengukuran total serum kalsium. ${ }^{22}$ Hanya kalsium terionisasi dapat digunakan oleh tubuh. Protein dan albumin dalam darah berikatan dengan kalsium sehingga mengurangi jumlah kalsium terionisasi yang bebas. Kalsium diperlukan untuk transmisi impuls saraf serta untuk kontraksi otot miokardium dan otot rangka. ${ }^{18}$ Diduga karena ion kalsium yang rendah akan terjadi penurunan ambang membran sel neuron terhadap ion kalsium sehingga terjadi depolarisasi yang berlebihan. ${ }^{23}$ Konsentrasi kalsium plasma akan turun sebesar $0,8 \mathrm{mg} / \mathrm{dL} \quad(0,2 \mathrm{mmol} / \mathrm{L})$ untuk setiap penurunan $1,0 \mathrm{~g} / \mathrm{dL}$ konsentrasi albumin plasma. ${ }^{24}$ Kadar kalsium darah yang sangat rendah dapat menyebabkan tetani atau kejang. ${ }^{25}$

Pada penelitian ini, kadar albumin rerata 2,16 \pm $0,79 \mathrm{~g} / \mathrm{dL}$ dengan kadar kalsium rerata 2,00 $\pm 0,20$ $\mathrm{mmol} / \mathrm{L}$. Hal ini menunjukkan jika kadar albumin rendah maka kadar kalsium juga akan turun. Hasil serupa juga didapatkan oleh Garniasih et al yang menemukan semakin menurun kadar albumin serum pada anak yang menderita sindrom nefrotik, semakin menurun kadar kalsium serum. ${ }^{17}$ Peneliti Hossain et $a^{R 6}$ mendapatkan korelasi positif antara kadar albumin serum dan kalsium terionisasi pada sindrom nefrotik idiopatik. Hal ini menunjukkan bahwa semakin rendah kadar albumin serum, semakin rendah kadar kalsium terionisasi serum.

\section{SIMPULAN}

Terdapat hubungan positif kuat antara kadar albumin dan kalsium serum pada anak dengan sindrom nefrotik. Penelitian ini menunjukkan jika kadar albumin rendah maka kadar kalsium juga akan turun. 


\section{UCAPAN TERIMA KASIH}

Terima kasih kepada pihak rumah sakit RSUP Dr Kariadi Semarang dan semua pihak yang sudah ikut membantu untuk proses penyelesaian penelitian ini.

\section{DAFTAR PUSTAKA}

1. Clark AG, Barratt TM. Steroid-responsive nephrotic syndrome. Dalam: Barratt TM, Avner TD, Harmon WE, editor (penyunting). Pediatric nephrology. Edisi ke-4. Baltimore: Lippincott Williams \& Willkins; 1999.hlm.731-47.

2. Travis L. Nephrotic syndrome. eMedicine.com. [diunduh 14 Apr 2005-versi terakhir]. Tersedia dari: http://www. emedicine.com/ped/topic1564.htm

3. Bhimma R. Steroid sensitive nephritic syndrome in children. Journal Nephrol Therapeutic. 2014; 11(3): 1-10.

4. Travis L. Nephrotic syndrome. Emed Journal. 2012;3(3):154-6.

5. Wirya IW. Sindrom nefrotik. Dalam: Alatas $H$, Tambunan T, Trihino PP, Pardede SO, editor (penyunting). Buku Ajar Nefrologi Anak. Edisi ke-2 Jakarta: FKUI; 2009.hlm.381-42.

6. Guha P, De A, Ghosal M. Behavior profile of children with nephrotic syndrome. Indian J Psychiatry. 2009;51:122-6.

7. Niaudet P. Steroid-sensitive idiopathic nephritic syndrome. Dalam: Avner ED, Harmon WE, Niaudet $\mathrm{P}$, editor (penyunting). Pediatric nephrology. Edisi ke-5. Philadelphia: Lippincott Williams \& Wilkins; 2004.hlm.545-73.

8. Ozkaya N, Cakar N, Ekim M, Kara N, Akkok N, Yalcinkaya F. Primary nephrotic syndrome during childhood in Turkey. Pediatr Int. 2004;46:436-8.

9. Ranganathan S. Pathology of podocytopathies causing nephrotic syndrome in children. Front Pediatr. 2016;4(March):32.

10. Pais $P$, Avner ED. Fixed proteinuria. Dalam: Kliegman RM, Stanton BF, Schor NF, Behrman RE, editor (penyunting). Nelson Textbook of Pediatrics. Edisi ke-19. Philadelphia: Elsevier Sauders; 2011.hlm.897-8.

11. Pais P, Avner ED. Nephrotic syndrome. Dalam: Kliegman RM, Stanton BF, Schor NF, Behrman RE, editor (penyunting). Nelson Textbook of
Pediatrics. Edisi ke-19. Philadelphia: Elsevier Sauders; 2011.hlm.898-900.

12. Prodjosudjadi W. Sindrom nefrotik. Dalam: Sudoyo AW, Setiyohadi B, Alwi I, Simadibrata M, Setiati S, editor (penyunting). Buku Ajar IImu Penyakit Dalam. Edisi ke-5. Jakarta: Pusat Penerbitan Departemen IImu Penyakit Dalam FKUI; 2009.hIm. 999-1003.

13. Davin JC, Rutjes NW. Nephrotic syndrome in children: from bench to treatment. Int $\mathrm{J}$ Nephrol 2011:1-6.

14. Gupta SK, Selvan VK, Agrawal, Saxena R. Advances in pharmacological strategies for the prevention of cataract development. Indian Journal of Ophtalmology. 2009; 57:175-83.

15. Greenbaum LA. Electrolyte and acid-base disorders. Dalam: Kliegman RM, Behrman RE, Jenson HB, Stanton BF, editor( penyunting). Nelson textbook of pediatrics. Edisi ke-18. Philadelphia: WB Saunders; 2007.hlm.267-309.

16. Ganong WF. Review of medical physiology. Edisi ke-20. New York: McGraw-Hill Inc; 2001.

17. Garniasih D, Djais T, Garna H. Hubungan antara kadar albumin dan kalsium serum pada sindrom nefrotik anak. Sari Pediatri. 2008;10:100-4.

18. Kee JL. Pedoman pemeriksaan laboratorium dan diagnostik. Jakarta: EGC; 2007.

19. Nickavar A., Hasanpour H. and Sotoudeh K. Validity of serum sodium and calcium screening in children with febrile convulsion. Acta Medica Iranica. 2009; 47(3): 229-31.

20. Kurniawan FB. Praktikum kimia klinik analis kesehatan. Jakarta: EGC; 2015.

21. Snodgrass SR. Neurologic manifestations of systemic illness. Dalam: Menkes JH, Sarnat HB, Maria $\mathrm{B}$, editor (penyunting). Child neurology. Edisi ke-7.hlm.1038- 40

22. Sharma J, Bajpai A, Kabra M, Menon PS. Hypocalcemia clinical biochemical radiological profile and follow up in a tertiary hospital in india. Indian Pediatr. 2002;39(3):276-82.

23. Prasad R, Singh A, Das B, Upadhyay R, Singh $T$, Mishra O. Cerebrospinal fluid and serum zinc, copper, magnesium and calcium levels in children with idiopathic seizure. Journal Of Clinical and Diagnostic Research. 2009;3(6):1841-6. 
24. Jain A, Agarwal R, Sankar MJ, Deorari A, Paul VK. Hypocalcemia in the newborn. Indian $J$ Pediatr. 2010;77(10):1123-8 .

25. Mulyani E. Konsumsi kalsium pada remaja di SMA 20 Jakarta Barat tahun 2009 (diakses 16 Desember 2017). Tersedia dari: http://lontar.ui.
ac.id/file?file=digital/126116-S-5733Konsumsi\%

20kalsium-Literatur.pdf

26. Hossain A, Mostafa G, Mannan KA. Correlation between serum albumin level and ionized calcium in idiopathic nephrotic syndrome in children. Urol Nephrol Open Access J. 2016;3(2):44-7. 